\title{
Campaigning for the Right to Legal and Safe Abortion in Brazil
}

\author{
Gilberta Soares and Cecilia Sardenberg"
}

Tensions ran high during the plenary session on the last day of the Second Conference for Public Policies for Women (II CNPM), held in August 2007 at the Brasilia Convention Center. More than 2,800 delegates, representing the nearly 300,000 women that participated in local and state preparatory conferences around the country, waited for the vote on the proposal for the legalisation of abortion to come up. Earlier in the day, word had gone around that anti-abortion groups, present in the conference room, were planning to obstruct the voting process. And it could certainly happen as heated confrontations between anti- and pro-abortion supporters had already taken place on the opening night of the Conference, even as Brazil's President Luis Inácio 'Lula' da Silva made his address.

As the vote drew nearer, pro-abortion mini-rallies filled the conference hall. $A$ large banner with the slogan for the Campaign for Safe Abortion 'Women decide, Society respects the decision, the State ensures its execution' - was carried around by activists of the Feminist Network for Sexual Rights and Reproductive Rights, enveloping the hall, while other groups and coalitions, with similar signs and banners, shouted pro-abortion jingles under the enthusiastic applause of the majority of participants. Finally, when hundreds of delegates raised their credential cards in support of abortion rights as the vote was finally called, it became clear that another battle had been won on the way towards the legalisation of abortion in Brazil.

This important stride came about, to a large extent, as a result of the efforts of the Jornadas Brasileiras pelo Direito ao Aborto Legal e Seguro (Brazilian Journeys for Legal and Safe Abortion), a coalition of 52 feminist organisations, 18 national networks and hundreds of individual women across the country. Jornadas was formed to advance women's struggles for reproductive rights, setting in its track a political process that has widened the range of partners and supporters. It was the first time that feminists in Brazil had engaged in such a proactive campaign to legalise abortion.

Drawing on the experience accumulated over more than 30 years of activism by contemporary feminist and women's movements in Brazil in the fight for the legalisation of abortion, and with the goal to 'win hearts and minds', Jornadas plans its interventions both within as well as outside of the feminist movements in Brazil and Latin America. It has adopted the principle of collective definition of political strategies and decision-making, incorporating the contributions of old and new partners through a constant process of dialogue. In this manner, it has promoted greater synergy within the feminist and women's movements. Jornadas has sought to construct a shared view of the issues at hand, and of possible ways forward. This has served to formulate a strategic plan that can articulate and catalyse all the different actions of the networks and organisations in the coalition in support of the overall aims.

These combined efforts have paid off. Indeed, Jornadas has propelled the campaign for the legalisation of abortion in Brazil onto a higher stage, bringing this important issue to the foreground of national debate. In what follows, we look into Jornadas' strategies in these campaigns, as well as at the recent backlash that their recognised successes have provoked.

\section{Abortion in Brazil: law and realities}

The panorama of abortion legislation in Latin America reflects the influence of religion - particularly the Catholic Church. Indeed, with the exception of Puerto Rico and Cuba, where voluntary abortions are legal, all 
other Latin American countries impose severe restrictions - and punishment - against those who defy the law. In 2007, however, feminists in Mexico City led a successful campaign to legalise voluntary first-trimester abortions in the city, and succeeded. Other victories have also been registered in Argentina and in Colombia, where abortion was legalised in May 2006 in cases of rape or incest, when the pregnancy endangers the life or health of a woman, and when the fetus is unlikely to survive (see Roa, this IDS Bulletin). Yet there have also been major setbacks. With strong lobbying from the Catholic Church, Nicaragua followed El Salvador in October 2006, voting against the legality of abortion under any circumstances, even when the mother's life is at risk.

Despite strict legislation, Latin American countries hold the distinction of having the highest abortion rates in the world, higher than in countries in Western Europe where access to legal abortion is good (Forero 2005). In Brazil, abortions have been defined as a 'crime against life', but since 1940, they have been allowed when pregnancy presents a risk to the life of the mother or as a result of rape. ${ }^{1}$ Despite prohibition for all other circumstances, it is believed that from 750,000 to 1 million clandestine abortions are performed in Brazil each year. As a result, nearly 250,000 women are admitted into public hospitals for care of abortion-related complications, 10 per cent of these women dying as a result, and approximately 20 per cent leaving with severe sequelae (Sugimoto 2005; Martins and Mendonça 2005). Most of these women are black and poor, as middle- and upper-class women can afford to pay for the high costs of having a safe abortion in sophisticated clandestine clinics.

Until recently, women could not count on the support of the state to have their rights recognised even in the cases prescribed by law. They not only had to deal with the many bureaucratic obstacles to have access to the procedure, but also faced the refusal of medical personnel in the public hospitals, as no legal and infrastructural provisions existed to guarantee what the law prescribed. As Rozeli Porto (CLAM 2006) notes, provision of abortion services is affected by the way the law is interpreted; as a result, many women are being treated badly, whether because of health providers' prejudice, because they are ignorant of the law or because they neglect their obligations. Besides, more often than not, by the time all the legal requirements are met, it is too late in the pregnancy for a woman to go through the medical procedures.

Although Brazil has never explicitly defined a population policy, since the 1960s, the average growth rate of the population has been going down considerably, with marked drops also in fertility rates (Villela 2001). However distribution of oral contraceptives and sterilisation procedures were confined to private family planning clinics until 1983 when these services became available in public health clinics through PAISM² (Programme for Comprehensive Women's Health), a programme that evolved to meet the demands of the women's health movement. As Villela (2001: 88) has noted, 'this initiative provided the first opportunity for feminists and the Health Ministry to work together'. In 1989, the first public health service providing the means for legal abortions was established in the state of São Paulo as a result of an alliance between the feminist movement, local government and health professionals. ${ }^{3}$ But it was not until the mid-1990s that other similar services were created across the country. Although most of them are concentrated in the south and south-eastern cities, they have been responsible for a significant increase in the performance of legal abortions in the country.

The provision of these services opened the way for significant developments such as the establishment of links between reproductive health and violence against women, both in terms of feminist action as well as in health services. Other important developments included making the state responsible for the provision of the needed services, the widening of the arena of debate regarding reproductive rights in Brazilian society, and the ratification of public opinion in favour of assisted abortions in the case of pregnancies resulting from rape.

The 1990s witnessed a change of mood in relation to women's reproductive rights. Indeed, in 1990, during the fifth Latin American and Caribbean Feminist Meeting, the 'September 28 Campaign' for the Decriminalisation of Abortion in Latin America was launched, with the support of women from 21 countries and seven regional networks. ${ }^{4}$ In addition, the 1990s were marked by a series of international conferences - the Rio Conference in 1992, the International Conference on Population and Development in Cairo and the Copenhagen Conference in 1994, and the 1995 International Conference in Beijing - that supported women's struggles for reproductive rights. 
The beginning of the year 2000 signalled the need to radicalise feminist action and propel the debate towards a more proactive campaign for the legalisation of abortion. It was in this context, in 2004, and precisely with this objective, that Jornadas was created.

\section{Campaigning for legalisation}

The legalisation of abortion has always been one of the major banners of the feminist movement in Brazil. ${ }^{5}$ Since 1991, when the 'September 28 Campaign' was first launched, it has been gaining supporters across the country. The Feminist Network for Health, Reproductive Rights and Sexual Rights, more commonly known as Rede Feminista de Saúde (Feminist Health Network), has been a major actor in that regard, as well as in leading the September 28 Campaign along with CLADEM, a Latin American network with similar goals. Their efforts have focused on three major avenues of action: (a) working with the Ministry of Health and local health officials and professionals to guarantee the availability of services for legal abortions; (b) building and monitoring changes in public opinion in favour of the legalisation of abortion, which has included monitoring the media; and (c) dealing with the law, particularly with the situation in the legislature (Villela 2001).

The latter has been a major focus of action. During 1991-8 no less than 24 different bills were presented to Congress on issues relating to the practice of abortion. Though most were favourable to granting greater reproductive rights to women, others were very restrictive, threatening existing rights. Indeed, until recently, a great part of feminist efforts towards the legalisation of abortion had been mainly 're-actions', in that feminists were often called upon to put out a 'fire' that threatened rights already established. Such a situation presented itself in 2003, when strong reaction on the part of those opposing the legalisation of abortion in the National Congress, particularly within the Family and Social Security Committee, became more threatening. On that occasion, some organisations and feminists who were dealing more directly with the issues decided to take account of the situation. It became clear that despite the numerous efforts on the part of a number of organisations, and in spite of some significant gains, most of these efforts had been fragmented: a more organised and systematised agenda was needed, so as to combine efforts and promote synergy. Moreover, it was necessary to move from a 'reactive' position to a 'pro-active' one.
In 2003, as a result of an intense process of political articulation, several sectors and organisations active in the feminist movement joined the September 28 Campaign, holding a number of different activities in several Brazilian cities. Coordinating the Campaign that year were Cunhã Coletivo Feminista (Cunhã Feminist Collective), the focal point for the campaign in Brazil, Rede Feminista de Saúde, and the Brazilian Catholics for the Right to Decide organisation. This process further motivated the groups and networks involved, fostering their active participation in the presidential race in which Luiz Inácio Lula da Silva President Lula - was elected, defending the legalisation of abortion. This created the conditions for the articulation of Jornadas Brasileiras pelo Direito ao Aborto Legal e Seguro around the slogan: 'Abortion should not be a crime. No woman should be arrested, fall ill or die because of an abortion'.

In 2004, aiming at changes in the Brazilian legislation regarding abortion, Jornadas was launched, defining participation in the First National Conference for Public Policies for Women ${ }^{6}$ as one of their major actions, so as to influence the formulation of these policies. This action was processual, in that they participated in the preparatory local and in the state conferences that brought together over 120,000 women across Brazil. With the exception of the state of Minas Gerais, all other state conferences approved the legalisation of abortion. And in the national conference, the 1,700 delegates present recommended the revision of abortion legislation as a compromise of the Brazilian government.

In the process of these conferences, Jornadas adopted the slogan: 'Abortion: Women decide, Society respects the decision, the State ensures its execution'? Later, this same slogan was adopted by the September 28 Campaign, today still the major theme in the struggle for the legalisation of abortion in Latin America. In tune with this theme, and to fulfil the recommendations of the national conference, the Lula government created a Tri-party Committee (Comissão Tripartite), constituted by representatives from civil society, and from the executive and legislative governmental bodies. Their major objective was to formulate a legal pre-project tending to the demands of the feminist movement to be presented to Congress. However, the process between the installation of the Tri-party Committee and the presentation of the project took place in a critical political period, marked by charges of 
corruption in the legislative body and in the ruling Workers Party.

Trying to allay the crisis, the Lula government made strategic changes in its cabinet and installed a Parliamentary Investigation Committee to examine the corruption charges. The matter occupied the national media for several months, as a vulnerable government in search of political support negotiated with members of the legislative body and with the Catholic Church. ${ }^{8}$ The Church took advantage of this situation, asking the Lula government to take a stand regarding reproductive life and sexuality, and demanding governmental opposition to abortion, homosexuality and stem cell research. The National Conference of Bishops of Brazil (Conferência Nacional dos Bispos do Brasil - CNBB) exercised political pressure directly over the Brazilian government, trying to avoid the installation of the Tri-party Committee, doing everything to generate public opinion unfavourable to the Lula government, by means of strategic actions focused at the media, parishes, publicity materials and public demonstrations.

Meanwhile, Jornadas and partners developed pressure strategies to garner political support within government so that Nilcea Freire, the Minister for Public Policies for Women, could gain the necessary support to present the project in Congress. The solution found was for Congresswoman Jandira Feghali, ${ }^{9}$ who was in charge of reporting on an older project on the matter to Congress, to adopt the results of the Tri-party Committee as her report. To that end, Jornadas lobbied within Congress to gain supporters for the project. By means of combined efforts, Jornadas conducted opinion surveys within Congress and organised women in the different states to bring pressure on their representatives in Congress to support Congresswoman Feghali.

The draft of the law legalising abortion finally arrived in the Congressional Committee for Social Security and the Family, circulating there for the last three months of 2005 and provoking strong reactions and counter-reactions. This had the effect of reducing the parliamentary base in support of the project. The political conjuncture, the proximity of the upcoming elections and the strong social pressure orchestrated by the Church created a very unfavourable climate for voting on the matter. Indeed, four different Parliamentary Fronts on the theme of 'In Defence of Life - Against Abortion' have emerged since, headed by Catholic and evangelical congressmen. This also came as a result of the debate surrounding the legalisation of abortion in the case of fetal malformation, especially in cases of anencephaly. During 2004, a number of women gained judicial support to have legal abortions on the grounds that they were carrying fetuses that could not survive birth. In June of that same year (2004), the National Council of Health Professionals (CNTS) and the nongovernmental organisation, ANIS, filed a class suit in the Supreme Court, asking for the authorisation to perform legal abortions in the public health network in cases of fetal anencephaly. And in May 2005, the Committee for Social Security and the Family symbolically approved Congresswoman Feghali's project, altering the Penal Code to include fetal malformation preventing life outside of the uterus to be among the exceptions to the law criminalising abortion.

A series of different surveys carried out during 2004 showed that public opinion favoured the legalisation of abortions in this particular case. A survey, conducted in October 2004 by Folha de São Paulo, the major newspaper in the country, found that 67 per cent of those interviewed supported it; among women, in particular, the percentage of supporters rose to 71 per cent. Similar high rates of approval were found in the survey conducted by the Brazilian Institute of Public Opinion (IBOPE) during November 2004, at the request of the Catholics for the Right to Decide organisation: 80 per cent of those interviewed agreed that it is a torture to the woman to be forced to carry a pregnancy to term when the fetus is known to suffer anencephaly. The important point here is that 70 per cent of women who declared themselves to be Catholic supported the proposed legislation (Feitosa n.d.).

Indeed, as noted by Piovesan and Pimentel (2003), in Brazil it is not religion, but rather the average number of years of formal education that defines the opinion of the Brazilian population regarding abortion. They cite a survey conducted by IBOPE in 2003 which found that whereas 55.3 per cent of those without formal education interviewed favour complete prohibition of voluntary abortions, this percentage falls to 9.2 per cent of those with a college education. This same survey showed that 63 per cent of those interviewed agreed that there should be no stepping backwards in the law regarding voluntary abortions. In this regard, a 
comparative analysis of 11 studies on public opinion in Brazil on the issue of voluntary abortions has indicated that 'the majority of the populations surveyed support abortion under a greater number of circumstances than are permitted by law' (Yam et al. 2006: 225).

Important advances in the way of securing women's reproductive rights were registered in this period. Of special note are the so-called 'Technical Norms' issued by the Ministry of Health to health professionals in the public health network. These establish use of the 'abortion pill' (also known as the 'morning after pill' and RU 436), particularly in the case of women victims of rape. They also establish that it is not required to have a police report registering the rape in order to gain access to safe, and in this case legal, abortion.

At the beginning of 2007 , the declarations of the Ministry of Health on the question of abortion played a major part in the construction of social debate on the topic, most of all in the run up to the visit by Pope Benedict XVI to Brazil. The Minister of Health defended women's right to decide and the responsibility of the state to guarantee access to safe abortion as part of the provision of public health services, along with the promotion of public debate and a plebiscite. The position taken by the minister contributed to an increasingly hot debate in the media on abortion, and this in turn fortified a perspective that was in favour of legalising abortion. The women's and feminist movements showed their support for the minister, who was heavily criticised by religious groups.

In 2007, Jornadas carried out two important actions of social mobilisation. The first was to post a message in defence of the legalisation of abortion, which announced the results of research on the anachronism of church rules in the context of the actual behaviour of Catholic Brazilians in front of Catholic churches around the country. ${ }^{10}$ The second was to take to the streets on 28 September, the designated day to promote the legalisation of abortion in Latin America and the Caribbean.

Meanwhile, the government was moving forward from permitting some of their representatives - the Minister of Health and the Minister of Women's Policies - to show themselves to be publicly in support of the decriminalisation of abortion, to initiating a process of revising the law. At the same time as they flinched from taking an official position, they were negotiating support for the project of revising the law. Their ambiguous stance was expressed by the way president Lula positioned himself; when grilled by the press, he tended to prevaricate, saying 'personally I am against abortion', but that women could not continue to die like this, evoking his responsibility as the head of state.

During the visit of Pope Benedict $X \mathrm{VI}$, the federal government affirmed the secularity of the state by not signing a concordat on religious education in state schools that was proposed by the Vatican. The president told the Pope that Brazil would 'preserve and consolidate the secular state', quite a novel attitude for a country that is so heavily influenced by Catholic values. The positioning of the government together with feminist activism on the right to abortion minimised the impact of the Pope's visit in relation to the legalisation of abortion. The debate had been put to Brazilian society, and there had been an advance in the mission of winning hearts and minds, and in increasing the number of allies, despite intensified opposition.

\section{Campaign strategies}

In carrying out its campaigns, Jornadas has made use of a range of different strategies.

\subsection{Promotion of public debate}

Taking account of the extent to which disinformation and the absence of debate leads people to adopt opinions without reflecting on their own position, and to the reproduction of values that are disseminated by the churches, Jornadas intensified the promotion of public debate. For this, they prioritised participatory methodologies and promoted dialogue through workshops, round tables and seminars with a variety of publics. Experience showed that people came to change their position, becoming more flexible and knowledgeable about why women sought abortion.

\subsection{Social mobilisation}

This promoted visibility of the issue, through demonstrations in the street at both national and local levels, with the production and distribution of communications material such as postcards, flyers, folders, magazines, leaflets and creative and artistic interventions that grab the attention of the media and the population. 


\subsection{Engaging the media}

Media engagement had two dimensions: (a) constant monitoring and mapping of forms of communication, both progressive and conservative; and (b) production of information qualified by research into public opinion, identification and diversification of sources of information, and training of leaders in order for them to better qualify their arguments and present themselves in the media.

\subsection{Amplifying alliances}

To gain more hearts and minds for the legalisation of abortion in Brazil, Jornadas saw the need to bring the debate to a wider constituency of organised social actors. These actors were seen as opinion makers, who could in turn influence their constituencies. Jornadas held strategic dialogues with operadores da justiça (operators of justice), doctors and health professionals, communication professionals, researchers and academics, social movements - the LGBT (lesbian, gay, bisexual, transvestite) movement, the human rights movement, the Black movement political parties and unions, in conjunction with the secretariat for women's policies, men and women from the rural workers' movements (Confederação dos Trabalhadores da Agricultura - Contag Movimento sem Terra - MST), and coalitions of youth, adolescents and students (União Nacional dos Estudantes - UNE e União Brasileira de Estudantes - UBES). The strategy for discussing abortion as part of the democratic agenda through inter-movement dialogues situated the legalisation of abortion as an important element for the construction of Brazil's democracy.

\subsection{Mobilisation within the women's and feminist movements}

The women's and feminist movements are of diverse composition. They are constituted as national networks and coalitions, which lends them to the possibility of consolidating a common agenda, developing viable coherent and concerted action in a country of continental dimensions. Information technologies played an important part in making this possible by minimising costs, favouring the flow of information, and enabling members of the movements to take collective decisions at a distance.

\subsection{Monitoring of the National Congress}

Actions have included systematic mapping of the opinion of legislators on the topic, accompanying bills that are on the agenda for vote, lobbying together with politicians, contacting deputies in their municipalities of origin to monitor their conduct during voting.

\subsection{Accompanying the juridical process}

Jornadas supported the formulation of a proposal presented to the Tri-party Committee to change the punitive legislation on abortion in Brazil, and legal support to women who are imprisoned for abortion, and gave an impetus to the debate on the political viability of a referendum on abortion in Brazil.

\section{Conclusion}

The campaign for the legalisation of abortion in Brazil is far from being over. But in looking at the contribution of the Jornadas Brasileiras pelo Direito ao Aborto Legal e Seguro in the four years since it was first launched, it is clear that it has made a significant contribution to advancing the struggles for reproductive rights as well as sexual rights in Brazil. Its success may perhaps be measured in terms of the reaction it has provoked, particularly on the part of the organised churches.

Among them, the Catholic Church, in particular, has emerged as a major enemy of women's rights and women's lives. The Church has the financial backing needed as well as the scope, through its parish system, to carry out a strong campaign, and is not being scrupulous about the means that are used. An example of how low the Church can stoop to achieve the goal of reducing women's reproductive rights is to be found in the distribution of plastic aborted fetuses to people who attended Sunday mass in Rio de Janeiro parishes in December 2007, with the full support of the local Bishop. The Church has also been behind the approval of local legislation prohibiting the distribution of the 'morning after pill' through the public health system in cities such as Recife, in Pernambuco, and Jundiaí, in São Paulo. Even if these approvals have been overthrown on the basis that they are unconstitutional, they have an impact on public opinion. And recently, the Church scored another point: it was instrumental in having the draft law elaborated by the Tri-party Committee defeated in the Congressional Committee for Social Security and the Family.

The backlash against the gains obtained for women by the feminist movement is also thriving in the judicial system. Nearly 10,000 women in the city of Campo Grande, in the state of Mato Grosso do Sul, are being tried for having had an abortion, some of 
whom have already been convicted. Of course, this backlash will not stop the campaigning for the legalisation of abortion in Brazil. However, it is clear that as Jornadas and partners take a more proactive role in this struggle, the need to continue 'firefighting' will remain. Indeed, as we move

\section{Notes}

* An earlier version of this article was presented by Gilberta Soares at the Marie Stopes International Global Conference on Safe Abortion, that took place in London in October 2007.

1 Brazilian Penal Code, Article 128.

2 Programa de Atenção Integral em Saúde da Mulher.

3 See Colas (n.d.) for a discussion of the implementation of such a programme in the state of São Paulo.

4 The 28 September is the International Day of Struggle for the Decriminalisation of Abortion.

5 See, for example Barsted (1997) for a discussion of feminist struggles for the legalisation of abortion.

\section{References}

Barsted, Leila Linhares (1997) 'O Movimento Feminista e a Descriminalização do Aborto' [The Brazilian Feminist Movement and the Decriminalisation of Abortion], Revista Estudos Feministas 5.2: 397-402

CLAM (2006) Aborto Invisivel em ano Eleitoral [Abortion Invisible in Electoral Year], 26 September, www.clam.org.br/publique/cgi/cgilua.exe/sys/ start.htm?infoid=1619\&tpl=pintervie (accessed 27 April 2008)

Colas, Osmar (n.d.) Aborto Legal por Estupro: Primeiro Programa Legal no País [Legal Abortion on Account of Rape: First Legal Program in Brazil], www. portalmedico.org.br/revista/biolv2/abortleg. html (accessed 25 May 2008)

Feitosa, Gileno (n.d.) Interrupção da Gestação em Caso de Anencefalia: Opinião de Mulheres de Classes Populares em Teresina-PI [Interruption of Pregnancy in the Case of Anencephalous Foetus: The Opinion of Women of the Popular Classes in Terezina, Piavi], www. portalbioetica.com. br/artigos/Gislenoll.07.0 6.pdf (accessed 25 February 2008)

Forero, Juan (2005) 'Push to Loosen Abortion Laws in Latin America', The New York Times, 3 December

Martins, A.L. and Mendonça, L.C. (eds) (2005) Aborto: Mortes Preveníveis e Evitáveis. Dossiê Aborto Inseguro forward, resistance to the securing of women's reproductive rights, fostered by the more conservative forces in our society, will continue to try to impose patriarchal restrictions on our way towards achieving full autonomy.

6 The conference was held by the Secretariat for Policies for Women, a governmental organ created by the Lula government to formulate and implement policies for gender equity.

7 'Aborto: As Mulheres Decidem, a Sociedade Respeita, o Estado Garante'.

8 See, for instance, Vargas (2005).

9 Jandira Feghali lost the elections for senate in 2006, victim of a defamatory campaign by the Catholic Church, who accused her of being an assassin for defending abortion up to the ninth month.

10 Research commissioned by Católicas pelo Direito de Decidir from the Brazilian Institute of Public Opinion (IBOPE).

[Abortion: Preventable and Avoidable Deaths], www.redesaude.org.br/dossies/assets/docs/revista _05.pdf (accessed 10 June 2005)

Piovesan, Flávia and Pimentel, Silvia (2003) 'Aborto, Estado de Direito e Religião', [Abortion, Legal State and Religion], Folha de São Paulo, 6 October

Sugimoto, L. (2005) 'Uma Mulher Morre a Cada três Minutos' [A Woman Dies Every Three Minutes], Jornal da Unicamp, Salda de Imprensa. Ed. 305. 10-17 October: www.unicamp.br/unicamp/ unicamp_hoje/ju/outubro2005/ju305pag04.html (accessed 26 October 2005)

Vargas, Xico (2005) 'Aborto, a Penitência de Lula' [Abortion, Lula's Penitence], No Mínimo, 9 September, www.nominimo.com.br (accessed 20 September 2005)

Villela, Wilza Vieira (2001) 'Expanding Women's Access to Abortion: The Brazilian Experience', in B. Klugman and D. Budlender (eds), Advocating for Abortion Access: Eleven Country Studies, Johannesburg: University of Witwatersrand: 87-108

Yam, Eileen A.; Dries-Daffner, Ingrid and Garcia, Sandra (2006) 'Abortion Opinion Research in Latin America and the Caribbean: A Review of the Literature', Studies in Family Planning 37.4: 225-40 